\title{
Investigating American Romanticism: A Comparative Study
}

\author{
Sabera Sultana, Md. Mohiul Islam
}

\begin{abstract}
American Romanticism, though formed being inspired by British Romanticism, has gradually been developed with certain distinctive features. This paper attempts to focus on those features by making comparison with those of British Romanticism. But this, in fact, is a comprehensive venture. So, this paper mainly investigates into the philosophies and ideas as Romantics from both sides of the Atlantics pursue and conceptualize.
\end{abstract}

The Romantic Movement, which originated in Germany but quickly spread to England, France, and beyond, reached America around the year 1820, some 20years after William Wordsworth and Samuel Taylor Coleridge had revolutionized English poetry by Publishing Lyrical Ballads. In America as in Europe, fresh new vision electrified artistic and intellectual circles. Yet there was an important difference.

Romanticism in America coincided with the period of national expansion and the discovery of a distinctive American voice. The solidification of a national identity and the surging idealism and passion of Romanticism nurtured the master-pieces of "the American Renaissance." Romantic ideas centered around art as inspiration, the spiritual and aesthetic dimension of nature, and metaphors of organic growth. Art, rather than science, Romantics argued, could best express universal truth. Thus this paper chooses some major American romantics as well as British to clarify the distinctive difference between American Romanticism and others, British in particular. The objective of this proposed paper is to establish the pragmatic approaches and challenges that American Romantics made and thus formed romanticism a distinctive one.

In American romanticism, the development of the "self" becomes a major theme; self-awareness a primary method. If, according to Romantic theory, self and nature were one, self-awareness was not a selfish dead-end but a mode of knowledge opening up the universe. If one's self were one with all humanity, then the individual had a moral duty to reform social inequalities and relieve human suffering. The idea of "self"-which suggested selfishness to earlier generations-was redefined. New compound words with positive meaning emerged: "self-realization", "self-expression", "self-reliance".

As the unique, subjective self became important, so did the realm of psychology. Exceptional artistic effects and techniques were developed to evoke heightened psychological states. The "sublime" — an effect of beauty in grandeur (for example, a view from a mountaintop) — produced feelings of awe, reverence, vastness, and a power beyond human comprehension.

Romanticism was affirmative and appropriate for most American poets and creative essayists. America's vast mountains, deserts, and tropics embodied the sublime. The Romantic spirit seemed particularly suited to American democracy: it stressed individualism, affirmed the value of the common person, and looked to the inspired imagination for its aesthetic and ethical values. Certainly the New England TranscendentalistsRalph Waldo Emerson, Henry David Thoreau, and their associates-were inspired to a new optimistic affirmation by the Romantic Movement. In New England, Romanticism fell upon fertile soil.

II

The idea of "self" was significantly important in American Transcendental Romantics-Emerson, Whitman, Thoreau. The Transcendentalist Movement in America, which was based on a fundamental belief in the unity of the world and God, was a reaction against $18^{\text {th }}$-century rationalism and a manifestation of the general humanitarian trend of $19^{\text {th }}$ century thought. The soul of each individual was thought to be identical with the world - a microcosm of the world itself. The doctrine of self-reliance and individualism developed through the belief in identification of the individual soul with God.

American Romantics pushed radical individualism to the extreme. Some of them often saw themselves as lonely explorers outside the society and convention. The American hero-like Herman Melville's Captain Ahab, or Mark Twain's Huck Finn, or Edgar Allan Poe's Arthur Gordon Pym—typically faced risk, or even certain destruction, in pursuit of metaphysical self-discovery.

Wordsworth proposed a philosophic view of the human soul, which is different from the views held by Plato on the same issue. Plato believes that human soul is immortal and exists separately from the body before birth and after death, but Wordsworth believes that the soul only gradually losses its vision after birth. 
This, in fact, is a contribution from Wordsworth on theory of knowledge in human beings pioneered by the great philosophers like John Lock, Immanuel Kant and Descartes. Lock doesn't believe in the possibility of a priori knowledge held by Kant and Descartes. Lock promotes the theory of Tabula rasa. He thinks that human mind can be taken as blank sheet of paper at its birth but it gradually gets filled up as human beings are exposed to the external world and gradually, with the tint of experience, acquires knowledge. So Lock believes in gradual development of concepts, ideas and, thereby, knowledge where- as Wordsworth thinks that knowledge in the form of vision fades away as human beings advances in years. As he says

There was a time when meadow, grove, and stream,

The earth, and every common sight,

To me did seem

Appareled in celestial light,

The glory and the freshness of a dream.

It is not now as it hath being of yore -

(“Ode: Intimations of Immortality”, 1-5)

So Wordsworth proposes a different epistemological idea which is different from both Plato and Lock.

Among the major British Romantic poets Wordsworth and Coleridge promotes some important ideas regarding the function of a poet's mind. Wordsworth believes that a poetic mind heavily relies on the data collected from the external world which later gets converted into in a phase of mind which he called 'Tranquility'. Poetry gets originated when the poet attempts to produce some lofty and powerful emotion which is very similar to those in the phase of tranquility.

Coleridge, in sharp contrast, believes that the poetic mind must rely on the intuitive knowledge for which the poet must look into the operations of his/her own mind. This can only be possible when the poet applies secondary imagination. His belief that the poet acquires inspiration or knowledge from the internal/inner function of mind has been expressed in one of his poems:

O Lady! we receive but what we give,

And in our life alone does Nature live:

Ours is her wedding garment, ours her shrouds!

And would we aught behold, of higher worth.

("Dejection: An Ode", 47-50)

Blake's epistemological theory takes 'The Universal Man' and not 'Any God' as it's starting point. For Blake, man is himself God and who incorporates the cosmos as well. Wordsworth thinks that human mind is the microcosm of the whole universe, that is, human mind has some potential or stimuli which can interact maintaining one to one correspondence with objects, animate or inanimate in the universe. In Blake's view, human mind cannot be thought of in isolation with the concept of universe whereas Wordsworth takes mind as a device for interaction with the universe.

An interesting comparison can be drawn on 'transcendentalism' held by the American romantics and Blake. For Blake the ultimate purpose is seeking the integrity of fallen aspects of human beings which he called 'the universal man' but Whitman and Emerson struggle to achieve a kind of intuitive knowledge which is tinted by a belief in a kind of 'Godhead' which substitutes the Christian God. Here Blakean substitution is 'the universal man' not any transcendental godhead.

Blake also develops his idea about the states of 'soul' which he identifies as 'innocence', 'experience' and 'higher innocence'. This Blakean cycle of development of human mind has been illustrated in his books of Songs of Innocence and Experience. Blake's ideas about the state of human mind can be contrasted with the Lacanian myth of development of human psyche in different phases with relation to progress of time. This phases, as Lacan identifies, are real (0-6 months), imaginary or mirror (16-18 months) and symbolic (18 months onwards). In the Blakean cycle of innocence, experience and higher innocence, Blake doesn't equate the progression of time in his theory of 'state of mind' but Lacan does.

John Keats contributes to philosophies and ideas by developing his theory of 'negative capability' and 'aesthetics'. He inclines equally toward a life of indolence and sensation and toward a life of thought. He is aware both of the attraction of imaginative dream world without "disagreeable" and the remorseless pressure of the actual; he aspires at the same time for aesthetic detachment what in his letters he called "negative capability" and for social responsibilities. The aesthetic detachment from sufferings and miseries of human life and his struggle to reach a land of perfection can be perceived from his poetry. His another drive for societal changes for progress can be traced from his lifelong temptation for 'beauty' that enables himself and his fellow people to achieve progress removing anomalies in human life. His task as an aesthetician thus removes the blemishes that he is an apolitical aesthete. 
Among other major and radical British romantics, Shelly attributed the evils of present society to man's own moral failures, and grounded the possibility of radical social reform upon a prior reform of man's moral nature through the redeeming power of love. Though often thought of as a simple minded doctrinaire, Shelly in fact possessed a complex and energetically inquisitive intelligence which never halted at a fixed mental position; all his writings represent, not final solution; but stages in a ceaseless exploration.

The poems of Shelly's maturity also show the influence of his study of Plato and the Neo- Platonists. Shelly found congenial the platonic division of cosmos into two worlds - the ordinary world of change, mortality, evil, and suffering, and the ideal world of perfect and eternal Forms, of which the world of sense experience is only distant and illusory reflection. The earlier interpretations of Shelly as a downright platonic idealist, however, have been drastically modified by recent investigations of his reading and writing. Shelly was a close student of English empirical philosophy, which limits knowledge to valid reasoning upon what is given in sense - experience and within this tradition he felt a special affinity to the radical skepticism of David Hume. Shelly was indeed an idealist, but as C. E. Pulos has shown in The Deep Truth: A Study of Shelly's Scepticism, his was "a qualified idealism," holding provisionally to the ideas he achieves by an imagination which transcends experience, but refusing to assert that these ideas are anything more than high possibilities.

As Shelly wrote, we quickly reach "the verge where abandon us, and what wonder if we grow dizzy to look down the dark abyss of how little we know." Many of his major poems express the limits of certain knowledge and the refusal to let his institutions; his hopes harden into a philosophical or religious creed. To skeptical idealism of the mature Shelly (e.g., lyrics from Hellas), the hope ion the ultimate redemption of life by love and imagination is not a certainty, but a moral obligation. We must cling to hope because it's contrary, despair about human possibility, is self-fulfilling, by ensuring the permanence of the conditions before which the mind has surrendered its aspirations. Hope does not guarantee achievement; it keeps open the possibility of achievement, and so releases man's imaginative and creative powers, which are its only available means.

Bertrand Russell in his History of Western Philosophy identifies his "Titan Cosmic Self-assertion". This, in fact, is an outlook and way of feeling that is very much within the Nineteenth Century philosophy which helped to form Nietzsche's concepts of the Superman. This, in fact, reflects the great hero who stands outside the jurisdiction of the ordinary criteria of good and evil. This is popularly taken as the "Byronic Hero" that occurs in men guises in Byron romances and dramas, but his central attribution is that of a saturnine, passionate, moody and remorse-torn but unrepentant sinner, who, in proud moral isolation, relies on his absolute self against all institutional and moral trammels. This figure, infusing the urge - rebel is a non political with a strong erotic interest, gathers, together and embodied the implicit yearnings of Byron's time, was imitated in life as well as in art, and helped to shape the intellectual as well as the cultural history of the later nineteenth century.

Emerson, one of the leading American romantics, develops his concepts of an ideal thinker or an intellectual in his essay "The American Scholar." This provides enough inspiration to his disciple Henry David Thoreau who devoted to his lifelong attempt in order to develop himself as an ideal intellectual as proposed by Emerson. Thoreau goes on to develop his concept of civil disobedient in his essay "Civil Disobedient" and practice activism in his protest against social injustice and slavery and unjust war, in particular, promoted by the American government.

Whitman's concept of self is an all - encompassing entity developed to combat all kinds of social injustice and anomalies within the society. His Leaves of Grass was inspired largely by Emerson's writings, especially his essay "The Poet", which predicted a robust, open-hearted, universal kind of poet uncannily like Whitman himself. The poem's innovative, unrhymed, free-verse form, open celebration of sexuality, and extreme Romantic assertion that the poet's self was one with the poem, the universe, and the reader permanently altered the course of American poetry.

Leaves of Grass is as vast, energetic, and natural as the American continent as he declares vigorously:

I celebrate myself, and sing myself,

And what I assume you shall assume

For every atom belonging to me

As good belongs to you.

Whitman seems to project himself into everything that he sees or imagines. His voice electrifies even modern readers with his proclamation of the unity and vital force of all creation. He was enormously innovative: From him spring the poem as autobiography, the American Everyman as bard, the reader as creator, and the still-contemporary discovery of "experimental" or organic, form.

In this sense, Emerson, Whitman and Thoreau stand for the same motto in their distinctive ways.

Whereas the American transcendentalists conceptualize their responsibilities in the macro level, Frost deals with the micro. Frost's idea of good poetry can be taken as a manifesto for developing a world worth living in. Frost believes that a good poem is also a good metaphor (quotation from Frost). Frost focuses on the particular on the micro but he does refer to the macro as well. In "Pasture," for example, he invites his readers or the fellow people to clear the passage of a waterfall so that common people can have easy excess to sources of 
water. This benevolent task is a powerful gesture to do good for the causes of humanity. This can also be compared with the "weak" postmodernists' belief in small attempts, dialogues, or negotiations to cement the gap between one human being to another. Frost, unlike British Romantic poets, does not philosophize Nature but takes Nature as it is, potential for both good and evil in human life. In "Design" he identifies the same attitude of love and awe, benevolence and malevolence, beauty and terror toward the mechanism of the world and mundane realities.

In "Stopping by Woods on a Snowy Evening," also, Frost focuses on a great human dilemma of making a choice between the ideal and the practical. This can be clearly perceived in the speaker's excuses to choose pragmatic view of life as he prefers to deny the temptation for the "lovely, dark and deep" woods, which stand for his intention to seek knowledge, preferring retreat to the mundane affairs as he says: "miles to go before I sleep."

Though the British Romantics belong to same country they do not speak of same thing. Even their philosophy is totally different from each other. Same thing happens in American Romanticism also. Though the American Romantics are more and less influenced by the British Romantics they try to treat the subject matter, writing style from their own perspective. They reflect the same thing in different lights- a thing is observed through different lenses. Here William Blake, Lord George Gordon Byron, Samuel Coleridge, William Wordsworth, Percy Bysshe Shelley and John Keats from British Romantics and Walt Whitman, Emily Dickinson and Robert Frost from American Romantics are compared from their individual traits.

Through nature Blake shows direct connection to both man and God. In his poem 'The Lamb' we find that he is saying-

Little lamb who made thee?

Dost thou know who made thee?

In these lines we see Blake gives his realization that God created Nature. Interestingly Blake uses the Lamb not only to depict one of God's creations, but God himself. In this way, God is being viewed as not only a part of Nature, but nature itself. A representation of purity and innocence are thus depicted. Man is also being seen as inherently pure and innocent as Blake refers to the reader as a child. He describes his view of nature like living creatures are not only created by god but they are also found in his image. So if we are part of nature then all the elements of nature are part of his image. So nature itself is not only a creation of God but also a reflection of God himself.

Wordsworth tries to find out inward sympathy with nature. He tries to follow different moods of nature. His romanticism basically founded on his treatment of nature. His passion to nature has three individual stages.

a. Boyhood: In this stage he emphasizes on the sensuousness of nature. The physical beauty and openness allure him.

b. Youth: He finds the echo of human sufferings in nature. The sad music of humanity is found in nature. Iniquity of human being, misunderstanding, melancholy all are found in nature.

c. Adult hood: In this stage he becomes the worshipper of nature. He finds God in nature. In fact, to Wordsworth, nature is a philosopher who can guide him and a nurse who can look after him.

Wordsworth's Lines Composed a Few Miles Above Tintern Abbey gives different aspects of nature. He states his view in the following lines-

I came upon these hills; when like a roe

I bounded o'er the mountains, by the sides

Of the deep rivers, and the lonely streams,

Wherever nature led...

For I have learned

To look on nature, not as in the hour

Of thoughtless youth; but hearing oftentimes

The still, sad music of humanity...(258)

These lines reveal the idea that man's existence in this world is not separate from nature, but very much a part of it. Man and Nature are inextricably one. Wordsworth views nature and all of its elements essential to human life. In these lines speaker states through its connection to Nature, mankind can experience earthly bliss not only in human form, but also in the form of any of nature's creatures. Man follows the path of nature. As it is revealed in these lines that nature is not a thing to be observed but it is such an intimate existence where we live and breathe in every dimension of human life.

Blake uses Nature to illustrate God and His glory. Whereas Wordsworth reveals Nature as a realm in which mankind can both reveal itself and live. Blake indicates that all elements of Nature reflect God's purity 
and beauty. Like Blake Wordsworth sees the pure beauty of Nature. In Tintern Abbey, the speaker can feel the direct connection between himself, humanity, and Nature.

On the other hand Byron revels in nature's grand and awe- inspiring aspect. To Byron nature is more than imagination.

Keats's sentiment of Nature is simpler than other romantics. He remains uninfluenced by the Pantheism of Wordsworth and Shelley. He loves Nature for her external charm and beauty. In Keats the sentiment of Nature is simple. He adores nature for his own sake. He does not try to find any kind of sympathy from nature. Rather he is the poet of the senses. He loves Nature because of her sensuous appeal- her appeal to the sense of sight, the sense of hearing, the sense of smell, the sense of touch. Keats is one of the supreme poets of Nature. To Wordsworth Nature is a living with power to influence man for good or ill. Keats neither gives a moral life to Nature like Wordsworth; neither tries to go beyond her familiar manifestations like Shelley. In Keats Nature poetry, realism or the quest for pure truth informs every detail. The instinct of Wordsworth is to interpret all the operations of Nature by his own sensuous soul.

For Shelley, natural beauty is symbolical in two fold senses-

a. In the visible glories of the world, his philosophy sees the evil of the unseen

b. All the visible glories of the world, he sees the vision of radiant future.

Shelley's poem is dominated by the sense of revolution. In the elements of nature he finds that the instruments are sacrificing themselves from the welfare of human being. But human beings are only thinking for themselves. Shelley invokes a strong force in his poetry to come and bring the world in order.

Wordsworth claims that nature is a moral guide and a universal mentor. Coleridge adds strangeness to the beauty by giving it supernatural touch. On the other hand Shelley intellectualizes nature. He finds intellectual attitudes from nature. Nature provides him vital energy to write poetry. Byron is interested in the vigorous aspects of nature. He uses nature for the purpose of satire. Coleridge emphasizes on inward nature of human being. If the mind is not good and fresh the outside world would not be good. He blends the natural with the supernatural. He tries to create a willing suspension of disbelief. He shows idealistic attitude which rests upon the reality of the human mind. He looks at external nature and tries to seek the symbols of his subjective thoughts and feelings rather than finding a new thought through observation. In the 'Dejection: An Ode he states that-

O Lady! We receive but what we give

And in our life alone does Natural live:

Ours is her wedding garment, ours her shroud! (46-48)

To him joy is the main thing that may tide nature and man.

American Romantics venerate nature as a sanctum of non artificiality. Self can fulfill its potential. American Romanticism is totally opposite to early Puritan as they see nature as fallen wilderness, full of savage. In American Poetry we find Robert Frost depicts both the simplicity and disastrous quality of nature. Frost is a true nationalist poet and the fact of regionalism is prominent in his poetry as, for the settings of his poems, he persistently uses the realm of rural New England. Various simple and familiar aspects of the domain of New England have been projected through the settings of his different poems, including the culture, lifestyle, weather and so forth. The very simple aspects of nature are thus manifested in his poetry. Alongside the pleasant phase, Frost sketches the sinister phase of nature as well in his poem - "Design" as he draws the idea of death through the metaphor of a moth caught by a white spider sitting on a white heal-all. He wants to depict the shocking essence of death designed within the beautiful and apparently simple and innocent natural setting. He puts forward the idea that, everything in the realm of nature is designed and there live the beauty and horror side by side. "Fire and Ice" projects the sinister nature of two very common but opposite emotions - love and hate, through the metaphors of fire and ice. The poet thinks, either the fiery desire of love or the icy blade of hate is capable enough to call the destruction on earth.

Dickinson highlights self-reliance or institution with conventional social and religious dogma. To Emily Dickinson the essence of nature is baffling, elusive and sometimes destructive. Like in the following poem we get her different attitudes towards nature. "It sifts from Leaden Sieves" (311) - gives the image of winter. The title of the poem does not suggest the falling snow which it describes. Leaden sieves suggest the sky and initially create sad moods. Then In the poem" I'll tell you how the sun rose", poet describes the sunrise and the sunset of same place. "A Narrow Fellow in the Grass"( 986) and "A Bird Came Down the Walk" (328) describe small creatures of nature. Here a narrow fellow is a snake. The narrator is a male. Probably the poet wants to describe the freedom of movement of the boy.

Blake presents his idea in a way that he shows his idea often comes from his encounter with an angel, a poet or a supernatural entity. Blake's early poems show his rebellious view on religion. In his poem "The Marriage of Heaven and Hell" he gives his view on dogmatic religion. He shows the contrast between Heaven 
and Hell, Good and Bad, Satan and the authorial deity. Here Satan is found fighting against the god head. Blake tries to bring the cruel aspects of human civilization into light through mythical character.

But Byron's use of allusion is pragmatic which is totally different from other romantics. Like in Don Juan, to describe the craziness and intensity of Juan's emotion, he gives the reference of Medea.

On the other hand, Keats attitude to nature has been compared with that of the ancient Greeks. The ancient Greeks personify the objects of nature. They call the moon Cynthia, the sun Apollo. They see the Dryads in the wood and Naiads in the water. In 'Ode to Psyche' he depicts the story of Psyche whom Venus jealous of. Again in 'Ode on a Grecian Urn' he reveals the common life of ancient Greeks. In Endymion and Hyperion, his myth making faculty in regard to nature is also manifested.

Shelley has a fond of mythology. In his poem Hellas he describes the Greek war of Independence, poetic beauty, celebration of creative imagination and its influence on man, a subject which is monotonous for human being.

Emily Dickinson considers God the supreme power, sometimes her friend and even sometimes she diminishes the position of God to a mere beggar. As in the poem 349 She states that-

\section{Angel-twice descending \\ Reimbursed my store- \\ Burglar! Banker- Father! \\ I am poor once more!}

Industrial Revolution and French Revolution influenced Blake a lot. He is critical about the rules imposed by the society and state. Blake is considered the fore runner of the "Free Love" movement started in $19^{\text {th }}$ century. Marriage is considered a slavery and all restriction imposed by the state on sexual activity is despised by him. He considered marriage a legal prostitution. His poem "London" speaks of "the MarriageHearse".

Byron heroes revolts against the dark holes of $19^{\text {th }}$ century society. They are self worshippers. He speaks about the unconscious, subconscious people of England and tries to make them conscious through the satire of his poetry. He transfers romanticism from poetry to life. He focuses on the hypocrisy and corruption of high society.

The early $19^{\text {th }}$ century America feels the changes brought to them by The Independence of America. In social perspective, American Romantics are radically egalitarian and politically progressive (Except Poe). Walt Whitman talks about democracy which is totally new idea to the American people.

Blake is influenced by Shakespeare, Spenser, Milton, Thomas Chatterton and other older styles. The Bible Ossian_and mystic writer influence him. In the Songs Blake uses tradition meter of English songs and hymns. His Poetical Sketches is written in lyrical blank verse. In the prophecies he uses free verse. In the prophecies he speaks as an orator and in the songs he sings in regular rhythm of a song. In the prophecies he delivers great message for his generation. He calls them to wake from sleep and asks them to engage in activity. But in the songs he delivers his word as a poet who sings because it is his duty.

Coleridge and Wordsworth give an elastic quality in the number of syllables and placement of their accent. This elastic quality gives a kind of spontaneous, free movement which helps to create an effect of involvement in the things of ordinary life. Wordsworth launches an attack on poetic diction in his "Preface to Lyrical Ballads". He likes the use of the language of 'men speaking to men' as a model.

S.T. Coleridge prefers particular language for poetry which he called 'poetic diction'. He does not believe in everyday language of people as the language of poetry. He likes to select words more consciously for his poem.

The American Romantics use symbol, myths, and fantastic elements. They try to focus on the protagonist's mental process. Their styles are very often original. They have their individual writing styles (Whitman writes like Whitman; Dickinson writes like Dickinson)

The simplicity of language is evident in Frost's poetry as many of his poems are utterly conversational, containing the simple and easy structure of sentences. Moreover, Frost very often tends to use the local vocabulary and familiar speaking voice to make his writings simple and easy to understand. The talking quality of his poem enhances the simplicity of his writing language.

Emily Dickinson's poems are written in short stanzas, mostly quatrains short lines, lining only on the second and the fourth lines. Iambic rhythms dominate Emily Dickinson's poems. They are varied, loosed, speeded and slowed. Most poems are off rhymes. She was conscious that she was violating conventional form. Her chief source was standard Protestant hymns of her day. Dickinson herself admits that the speaker in her poem is a fictitious person. It is not herself. There are various speakers in her poem. Reader finds a problem to distinguish the voice. This makes the mind nimble. Probably Dickinson wants to keep her mind and the reader's 
mind nimble. She uses dashes, more punctuation marks, spaces in her poetry. Like in her poem \#199 she states that

$$
\begin{aligned}
& \text { I'm 'wife' - I've finished that- } \\
& \text { That other state- } \\
& \text { I'm Czar- I'm 'woman' now- } \\
& \text { It's safer so-(1-4) }
\end{aligned}
$$

Blake has contempt for empiricist philosopher. They emphasizes on sense perception instead of vision. These philosophers cease imaginative force. Thus human souls gradually fill up with hypocrisy, self seeking instincts. Blake has his own philosophy of life.

He deals with two contrary states of human mind. He tries to show this difference between these two parts. His great maxim "without contraries is no progression". He focuses on the imaginative vision or the state of innocence and how the harsh reality changes and destroys that. He chooses pastoral setting for his poetry. William Wordsworth speaks of simple incident and humble people. The French Revolution and the social and political thought influence him. Development in the psychological field like Locke's view of perception and knowledge and the influence of Enlightment impact on his poetry. Wordsworth depicts the sense of loss through his craving for pastoral life. He depicts that people loose their pastoral life as they gradually grows from childhood to adulthood. But to Blake this sense of loss has wider meaning. He says childhood is a symbol of a state of soul which may prevail after being matured. Shelley has a passionate devotion in science for its own sake and for the betterment of human being. In his poetry he tries to give the idea of scientific philosophy.

American Romantics focus on Democracy. Democracy brings all to an equal level. There is no longer the traditional old hierarchy system. But there arises a problem. American Romantics support democracy and thus arise the dignity of common folk. But implicitly they feel the loss of distinction between different classes for this. The American Romantics celebrate the 'common man' and try to prove them spiritually/ psychologically elite.

Events and incidents presented in the poetry of Robert Frost are also from the familiar New England life which dealing with simple emotion and thought of the common mass. Many readers of common mass would find different incidents of their own, depicted in the poetry of Frost. On the other hand Dickinson blends trivial things with the precious. She draws our attention to small things but wants to focus on large texture

To Wordsworth, poetry is primarily the record of a certain kind of state of mind. Value of poetry lays in the value of the state of mind. A poet for him is a man of unusual emotional vitality who has an excellent perception of his fellow men and of the world. He wants to find the psychological and the moral truths underlying all existence. His high moments of perception, creates an emotion.

To Byron, poetry is not much different from life. He lives to his own poetry. He tries to free poetry from Gaudiness and inane phraseology. He maintains the historical characteristics of poetry. But at the same time prevents poetry from being a wholly special territory of ultra sensitive spirits.

To Keats, a poet is a creator and an artist not a prophet. He thinks that poetry should be unobtrusive. He focuses on beauty rather than the objective of social reform. Poetry is not an instrument of social revolt or philosophical doctrine rather poetry is an expression of beauty. In "Endymion", he says that "A thing of beauty is a joy for ever'. His poetry is called the poetry of earth because he tries to enjoy the sensuous beauty of nature only.

Dickinson is a poet of rural $19^{\text {th }}$ century New England. She reads Wordsworth, Bryant and Emerson's poetry which always search for meaning and spiritual refreshment- the characteristics of Romantic Movement. This thing influences her poetry. Her believe in Puritanism which sees God manifested in everywhere develops her view about nature.

Wordsworth's moral view is connected to mysticism. He gets a kind of transcendental feeling of ecstasy and consciousness that help him to build up his morality.

To Walt Whitman, one has to have a mystic journey towards spiritual highness intending to reveal the true identity of God. Thus spiritual journey radiates the real spice of enigma and mystery through the way. Mysticism thus has its appeal truly felt among the readers of Song of Myself. The poet describes his soul as an all- inclusive one. He diffuses his soul in everything and he sees everything as diffused in his soul. Therefore his soul stands for all. This idea all inclusion makes the poet a micro level observer of anything and everything, material and abstract, physical and mental. He qualifies himself a worthy one to observe and explain each and every element of nature- including human being, animal and even a grass. In this way he prepares himself for his spiritual mystic journey transcending the worldly barrier. Then the poet evaluates body along with soul and gives equal importance to both of them. He emphasizes on the harmonies co-ordination of body and soul before the self's transcendental journey. He says, 'I am the poet of the Body and I am the poet of the Soul'. Starting from a grass- leaf, the poet transcends the frame of earth and speeds through the outer space and beyond as he says;

Speeding through space, speeding through heaven and the stars,

Speeding amid the seven satellites and the bread ring, and the diameter of eighty thousand miles... 
I tread day and night such roads.

The poet's mysticism ascends on and on to be ended with a self realization, where he finds his self as an immortal one and finds the deathless infinity and eternity.

Body is a materialistic phenomenon while soul is a spiritual one. Life is a journey where both of these two have their own role to play and without a balanced co- ordination of these two, the drama of life can not be acted out properly. In romantic poetry often the visionary faculty is found to interact with Nature. In The Prelude Wordsworth speaks of the child's mind interacting with Nature. The individual subject is responding with a transcendental subject or spirit. The tension between subject and object is often found in romantic poetry. This tension is resolved in an idealist way where correlation between the individual mind and the mind of absolute are shown.

Whitman's Song of Myself can be considered an adventure of seeking identity. In every situation, incident or experience we find Whitman is seeking his identity. Through the going process of poem we find him creating a relation between him and the reader. He focuses in the process of celebrating himself. But he does not focus only his limited self but his inner self also. To Whitman one has to identify his self. Without the self realization the ultimate quest of life can not be ended where the identity of God is supposed to be revealed and the real satisfaction is supposed to be gained. The quest for divine unity is a mystic journey. To Whitman either of body and soul must not be abased regarding to the other. Each one has to get equal importance and the role of both should be celebrated to achieve the ultimate satisfaction. The poet says:

I have said that the soul is not more than the body

And I have that the body is not more than the soul.

Again the poet says belief and trust for one's soul is important. He says' I believe in you my soul'. The poet celebrates the body, bodily beauty and strength, even that of the animals. He also celebrates the physical sexuality and even makes it sublime.

Both Wordsworth and Whitman admit the harmonies combination of body and soul. They recognize the necessity of this harmony because it is necessary to identify God.

\section{III}

This paper has attempted to find out and then explain the major contributions from the six major British Romantic poets and also the first generation of Romantics from America. The American Transcendentalists, Emerson, Thoreau, and Whitman, in particular, have established the concept of hyper individualism of "self" in its most radical form. Wordsworth, Blake, Shelley, and Byron also developed "self". This paper, therefore, focuses on their ideas as well. Next, Blake and Wordsworth conceptualize the origin of knowledge that has been compared with the ideas held by Plato, Whitman, and Emerson. Finally, the paper has attempted to concentrate on some other points of comparison between the British and the American Romantics.

\section{BIBLIOGRAPHY}

[1]. Abrams, M.H. The Norton Anthology of English Literature. Vol ii. $6^{\text {th }}$ ed. Norton: New York.

[2]. Baym, Nina, The Norton Anthology of American Literature. Vol i. $3^{\text {rd }}$ ed. Norton: New York.

[3]. Bloom, Harold, ed. English Romantic Poetry.vol ii. New York: Anchor Books, 1963. Print.

[4]. Cohen, Murray. The Poetry of Percy Bysshe Shelley. New York: Monarch Press, 1965. print.

[5]. Daiches, David. A Critical History of English Literature. Vol iv. New Delhi: Allied Publishers, 1994. Print.

[6]. Day, Aidan. Romanticism. Routledge: London,1998. Print.

[7]. Drabble, Margaret, ed. The Oxford Companion to English Literature. $5^{\text {th }}$ ed. Oxford: Oxford UP

[8]. James, D.G. Matthew Arnold and the Decline of English Romanticism. Oxford: Claredon Press,1969. Print. 